\title{
THE LIBRARY DEVELOPMENT BASED ON SOCIAL INCLUSION: SWOT ANALYSIS AND SOCIO-RELIGIOUS ROLE
}

\author{
Moch Lukluil Maknun ${ }^{1}$, Umi Muzayanah ${ }^{1}$, Muhamad Khusnul Muna ${ }^{1^{*}}$ \\ Andjar Prasetyo ${ }^{2}$, Milta Eliza ${ }^{3}$ \\ ${ }^{1}$ Kementerian Agama - Balai Penelitian dan Pengembangan Agama Semarang, Indonesia \\ ${ }^{2}$ Badan Penelitian dan Pengembangan Kota Magelang, Indonesia \\ ${ }^{3}$ Perpustakaan Muda Bhakti Magelang, Indonesia \\ *Corresponding author: m.khusnulmuna@gmail.com
}

\author{
(c) (1) (2) \\ (C)2021 by the authors. Submitted for possible open access publication under the terms and conditions \\ of the Creative Commons Attribution-ShareAlike 4.0 International License (CC-BY-SA) \\ license (https://creativecommons.org/licenses/by-sa/4.0/) \\ doi DOI: http://dx.doi.org/10.30983/fuaduna.v5i2.4915
}

\begin{abstract}
Rural libraries have an essential role in providing information services for rural communities. The heterogeneity of rural communities from social, economic, and religious aspects is the basis for the importance of social inclusion-based library services. This study uses qualitative methods to describe the implementation of an inclusion-based village Perpustakaan Muda Bhakti (Permubha) Ngablak Village, Srumbung District, Magelang Regency and its role in the social, economic, and religious life of the village community. Through a SWOT analysis, this study resulted in several research findings. First, three things become Permubha's strengths in providing services: information disclosure and access policies, communication in services, and circulation of library facilities. Second, Permubha's weakness is the unavailability of a computer-based library catalog. Third, the opportunities/opportunities that exist in Permubha are descriptive and normative officer ethics, responsibility in providing services, the role of citizen donations, and infrastructure. Fourth, Permubha has several challenges ahead in terms of service evaluation, increasing the competence and qualifications of officers, and increasing responsibilities. Fifth, in addition to library services, Permubha plays a role in social, economic, and religious activities through programs that can be participated in by the Ngablak Village community, such as the salak library program, Suluh Libraries, satellite reading, and commemoration of Islamic holidays.
\end{abstract}

Keywords: Rural library; Social inclusion; SWOT analysis.

\begin{abstract}
Abstrak
Perpustakaan desa memiliki peran penting dalam memberikan layanan informasi bagi masyarakat desa. Heterogenitas masyarakat desa dari aspek sosial, ekonomi, dan agama menjadi dasar pentingnya layanan perpustakaan berbasis inklusi sosial. Dengan menggunakan metode kualitatif, penelitian ini bertujuan untuk mendeskripsikan penyelenggaraan perpustakaan desa berbasis inklusi pada Perpustakaan Muda Bhakti, (Permubha) Desa Ngablak Kecamatan Srumbung Kabupaten Magelang serta perannya terhadap kebidupan sosial, ekonomi, dan keagamaan masyarakat desa. Melalui analisis SWOT, penelitian ini menghasilkean beberapa temuan penelitian. Pertama, ada tiga hal yang menjadi kekuatan Permubha dalam memberikan layanan, yaitu keterbukaan informasi dan kebijakan akses, komunikasi dalam layanan, dan sirkulasi sarana perpustakaan. Kedua, kelemahan yang dimiliki Permubha adalab belum tersedianya katalog pustaka berbasis komputer. Ketiga, peluang/kesempatan yang ada di Permubha adalah adanya etika petugas secara deskriptif dan normatif, tanggungjawab dalam memberikan layanan,
\end{abstract}


adanya peran donasi warga, dan sarana prasarana. Keempat, Permubha memiliki beberapa tantangan ke depan dalam hal evaluasi layanan, peningkatan kompetensi dan kualifikasi petugas, dan peningkatan tanggung jawab. Kelima, selain layanan pustaka, Permubha berperan dalam kegiatan sosial, ekonomi, dan keagamaan melalui program-program dapat diikuti oleh masyarakat Desa Ngablak, seperti program salak pustaka, sulub pustaka, satelit baca, dan peringatan PHBI.

Kata Kunci: Perpustakaan desa; Inklusi sosial; Analisis SWOT.

\section{INTRODUCTION}

The village library is one of the important pillars in promoting literacy campaigns in the community. It is important considering that the village library is still considered a lagging library because its users do not follow the sophistication of existing information technology ${ }^{1}$. On the other hand, village libraries must provide inclusive information services, which do not discriminate against anyone based on their inherent attributes such as age, ethnicity, gender, religion, nationality, language, and social status ${ }^{2}$. The village library is a place for providing reading materials as a source for the community in order to educate and empower the community ${ }^{3}$. One of the criteria for people who are excluded is those who do not have access to the library for various reasons, one of which is that they do not have the time or opportunity to go to the library because of distance and busyness so that they become the excluded group. ${ }^{4}$

On the other hand, the library is very important because it has knowledge and lifelong

1 A Jananto, Pandangan Sekolah Terhadap Penyelenggaraan Pendidikan Inklusif Di Kabupaten Bangka Barat (repository.upi.edu, 2016), http://repository.upi.edu/id/eprint/25801;M U Noor, "Aplikasi layanan informasi berbasis internet untuk menumbuhkan inklusi sosial di perpustakaan daerah," JIPI (Jurnal Ilmu Perpustakaan dan Informasi), 2019, http://jurnal.uinsu.ac.id/index.php/jipi/article/view/4122.

${ }^{2}$ Feri Dwi Haryanto, "Strategi Pengembangan Minat Baca Di Perpustakaan Muda Bhakti," E-Jurnal Skripsi Program Studi Teknologi Pendidikan 8, no. 5 (2019).

${ }^{3}$ D Utami and W D Prasetyo, "Perpustakaan Berbasis Inklusi Sosial Untuk Pembangunan Sosial-Ekonomi Masyarakat," ... Informasi Antar Perpustakaan, 2019.

4 R A Rachman and D Sugiana, "Strategi Sukses Transformasi Perpustakaan Desa Berbasis Inklusi Sosial Untuk Masyarakat Sejahtera (Studi Pada Perpustakaan Desa Gampingan Gemar ...," Seminar Nasional MACOM ... (researchgate.net, 2019). learning ${ }^{5}$. Social inclusion-based libraries are an approach to library services that are committed to improving the quality of life and welfare of the library user community ${ }^{6}$. This improvement effort is pursued by developing a library that prioritizes community empowerment programs ${ }^{7}$. It is hoped that with this program, libraries, especially village libraries, can also play an active role in realizing the success of various sustainable development programs through community empowerment.

Law Number 43 of 2007 concerning Libraries in Article 2 states that "Libraries are organized based on the principles of lifelong learning, democracy, justice, professionalism, openness, measurability, and partnership". It shows that the library has a mandate as a place of learning and partnership that is managed professionally and is open to all groups to create a just society and measure performance achievements for the community's welfare. Lifelong learning is the keyword in the development of social inclusion-based library transformation. Libraries can take on a role not only as an information center, more than that the library can be transformed into a place for

5 A Surachman, "Undang-Undang Nomor 43 Tahun 2007: Peluang Dan Tantangan Bagi Pustakawan" (repository.ugm.ac.id, 2009).

6 W D Prasetyo and D Utami, "Penguatan Perpustakaan Untuk Pembangunan: Sebuah Konsep Transformasi Berbasis Inklusi Sosial," Jurnal IPI (Ikatan Pustakawan Indonesia) (ipi.web.id, 2020).

7 A S Rohman and S Sukaesih, Transformasi Perpustakaan Desa Untuk Pemberdayaan Masyarakat: Studi Kasus Di Desa Margamukti-Pangalengan Bandung (repository.pertanian.go.id, 2018).

8 Surachman, "Undang-Undang Nomor 43 Tahun 2007: Peluang Dan Tantangan Bagi Pustakawan." 
community self-development so that it can improve the welfare of the community ${ }^{9}$.

In the era of the new normal (new normal), libraries are required to play a role in strengthening literacy so that it impacts socioeconomic recovery. The library has become a public space for sharing experiences, learning contextually, and practicing skills. The library has carried out the role of literacy in realizing a prosperous society through the transformation of library services based on social inclusion. The Social Inclusion-Based Library Transformation Program aims to strengthen the role of public libraries in improving the quality of human resources so that literacy skills will increase which will lead to increased community creativity and narrowing gaps in access to information.

In practice, the library provides reading sources to explore information and knowledge is also obliged to facilitate the community with various training and skills activities. It aims to empower the socio-economic community so that it is hoped that individual performance will increase, which can automatically increase community literacy. The realization of this transformation is a manifestation of the role of the library as a center of knowledge, a center for community activities, a cultural center, and a forum for facilitating the community to develop their potential ${ }^{10}$.

Several areas have been intervened by the existence of social inclusion-based literacy, including six villages in Labuhanbatu Regency; five villages in Deli Serdang Regency, and six villages in Serdang Bedagai ${ }^{11}$. Magelang Regency has initiated the village library by establishing the

9 Prasetyo and Utami, "Penguatan Perpustakaan Untuk Pembangunan: Sebuah Konsep Transformasi Berbasis Inklusi Sosial"; Rohman and Sukaesih, Transformasi Perpustakaan Desa Untuk. Pemberdayaan Masyarakat: Studi Kasus Di Desa Margamukti-Pangalengan Bandung.

${ }^{10}$ Hanna Meinita, "Rayakan Hari Jadi Ke-41 Tahun, Perpusnas Punya 10 Modal Wujudkan SDM Unggul," https://www.perpusnas.go.id/, 2021.

11 Meinita.
Young Bhakti Library in Ngablak Village, Srumbung District. This program correlates with social inclusion because it can encourage public awareness from various walks of life, both children and women. In the context of women being able to impact economic empowerment and sustainable social interaction. The process has long stages, but can become a positive reference in literacy, as well as provide useful social impacts.

Perpustakaan Muda Bhakti (Permubha) also has several programs contributing to economic empowerment and social interaction. Among these programs is the Salak Pustaka Program which is used to improve the quality of Permubha so that people can be interested in using it. The Suluh Pustaka (Suka) program has four programs: reading, liking the environment, being alert to disasters, and liking Jam Belajar Masyarakat (JBM). The Reading Satellite Program is implemented in Permubha to reach all levels of society in Ngablak Village, considering that Ngablak Village consists of seven hamlets. The Karya Pustaka program itself consists of three programs, namely say science, say art, and say processed bark ${ }^{12}$. The program is given to the community so that they can become a creative community and can produce a product so that they can compete with others.

Many studies on inclusive libraries have been carried out, both related to development strategies $^{13}$, librarian's role $^{14}$, service mode $^{15}$, and

12 Milta Eliza, "Pofil Perpustakaan Muda Bhakti Desa Ngablak, Kec. Srumbung, Kab. Magelang” (Kabupaten Magelang: Perpustakaan Muda Bhakti, 2019); R. Arri Widyanto et al., "Pengelolaan Perpusdes Dengan Ingkubasi Wirausaha Di Perpustakaan Muda Bhakti Desa Ngablak Srumbung: Laporan Akhir Pengabdian Masyarakat Terpadu (PPMT) Universitas Muhammadiyah Magelang," Universitas Muhammadiyah Magelang, 2020.

$13 \mathrm{~K}$ Khairunisa and W Dastina, "Strategi Dinas Perpustakaan Dan Arsip Daerah (DPAD) Provinsi Jambi Dalam Mengembangkan Perpustakaan Berbasis Inklusi Sosial Untuk Mewujudkan Masyarakat ...," ... Ilmu Perpustakaan ..., 2020; Rachman and Sugiana, "Strategi Sukses Transformasi Perpustakaan Desa Berbasis Inklusi Sosial Untuk Masyarakat Sejahtera (Studi Pada Perpustakaan Desa Gampingan Gemar ...." 
inclusion models ${ }^{16}$ itself. Likewise, many studies related to the literacy level of the Indonesian people have been carried out ${ }^{17}$. Studies or reports that take the object of the Muda Bhakti Library have only found three articles that focus on reading interest strategies, entrepreneurial incubation, and activity reports on library management ${ }^{18}$. As an effort to complement existing studies, this study specifically deepens the description of the role of the Permubha library in the socio-religious field, as well as measuring the analysis of the implementation of inclusive libraries using the SWOT method.

Furthermore, this study can be classified as a qualitative descriptive study. Field data collection was carried out in June 2021 by taking

${ }^{14}$ H S Adhi, "Peran Pustakawan Dalam Mewujudkan Layanan Perpustakaan Berbasis Inklusi Sosial Melalui Program Proliterasiku," Jurnal IPI (Ikatan Pustakawan Indonesia) (ipi.web.id, 2018); Prasetyo and Utami, "Penguatan Perpustakaan Untuk Pembangunan: Sebuah Konsep Transformasi Berbasis Inklusi Sosial."

15 G B B Sembiring, "Taman Baca Pustaka Sebagai Perluasan Layanan Perpustakaan Khusus Berbasis Inklusi Sosial," ... Jaringan Informasi Antar Perpustakaan, 2020; Noor, "Aplikasi Layanan Informasi Berbasis Internet Untuk Menumbuhkan Inklusi Sosial Di Perpustakaan Daerah."

16 Sembiring, "Taman Baca Pustaka Sebagai Perluasan Layanan Perpustakaan Khusus Berbasis Inklusi Sosial"; Khairunisa and Dastina, "Strategi Dinas Perpustakaan Dan Arsip Daerah (DPAD) Provinsi Jambi Dalam Mengembangkan Perpustakaan Berbasis Inklusi Sosial Untuk Mewujudkan Masyarakat ...."

17 Billy Antoro, Gerakan Literasi Sekolah: Dari Pucuk Hingga Akar, 1st ed. (Jakarta: Direktorat Jenderal Pendidikan Dasar dan Menengah Kementerian Pendidikan dan Kebudayaan, https://doi.org/10.1017/S0033291700036606; 2017)

Darmayanti, "Membangun Budaya Literasi Informasi Bagi Masyarakat Kampus," IQRA: Jurnal Ilmu Perpustakaan Dan Informasi (e ... (jurnal.uinsu.ac.id, 2016); Agus Iswanto et al., "Praktik Literasi Mahasiswa Universitas Islam Negeri Di Yogyakarta, Jawa Tengah, Jawa Timur, Nusa Tenggara Barat, Dan Kalimantan Selatan" (Semarang, 2018); N Kimiaissa'adah, Implementasi Gerakan Literasi Membaca Dalam Menumbubkembangkan Minat Baca Anak Usia Dini Di TK IT Mutiara Hati Semarang (lib.unnes.ac.id, 2019).

18 Haryanto, "Strategi Pengembangan Minat Baca Di Perpustakaan Muda Bhakti"; Widyanto et al., "Pengelolaan Perpusdes Dengan Ingkubasi Wirausaha Di Perpustakaan Muda Bhakti Desa Ngablak Srumbung: Laporan Akhir Pengabdian Masyarakat Terpadu (PPMT) Universitas Muhammadiyah Magelang." the object of the Young Bhakti Inclusion Library located in Ngablak Village, Srumbung, Magelang Regency. Measurement of library management can be seen from various aspects, as is also done regularly from the library accreditation team. The main aspects that are seen include service, personnel, as well as technical and non-technical aspects. Service aspects include information disclosure and access, communication, circulation, reference services, types of collections, to service evaluation. Aspects of officers include professional competence, ethics, responsibility, and competency development. Technical and non-technical aspects include collection, processing, publication, and so $\mathrm{on}^{19}$. In addition to observing the state of the library and the surrounding community, interviews were conducted with librarian officers, founders, and local community leaders.

The existence of social inclusion-based libraries can be understood in at least four aspects known as SWOT (Strength, Weakness, Opportunity, and Threat). Strength is an added value that exists in the library, Weakness is a deficiency that has been present in the library, Opportunity regarding other things that can be maximized that can contribute to the library, and Threat is any obstacles that all this time hindering the transformation process of inclusive libraries in $\mathrm{Ngablak}^{20}$. If these four aspects can be mapped

19 Sutarno NS, Tanggung Jawab Perpustakaan Dalam Mengembangkan Masyarakat Informasi (Jakarta: Panta Rei, 2005); Sutarno NS, Manajemen Perpustakaan: Suatu Pendekatan Praktik (Jakarta: CV. Sagung Seto, 2006); Elva Rahmah, Akses Dan Layanan Perpustakaan: Teori Dan Aplikasi (Jakarta: Prenadamedia Group, 2018); P Sumardji, Mengelola Perpustakaan, 17th ed. (Yogyakarta: Penerbit Kanisius, 2013).

20 T Hill and R Westbrook, "SWOT Analysis: It's Time for a Product Recall," Long Range Planning, 1997; G Houben, K Lenie, and K Vanhoof, "A Knowledge-Based SWOT-Analysis System as an Instrument for Strategic Planning in Small and Medium Sized Enterprises," Decision Support Systems, 1999; S E Jackson, A Joshi, and N L Erhardt, "Recent Research on Team and Organizational Diversity: SWOT Analysis and Implications," Journal of Management, 2003; M Kurttila et al., "Utilizing the Analytic Hierarchy Process (AHP) in SWOT Analysis-a Hybrid 
and maximized properly, the implementation of libraries in social inclusion is sustainable and is believed to be applicable to other areas in Magelang Regency.

Based on the SWOT concept above, it is necessary to conduct a study considering the value of the benefits obtained and the absence of a scientific foothold in the practice of libraries playing a role in social inclusion in Magelang Regency. The context studied leads to the identification of the role of libraries not only in terms of increasing public interest in reading but also as a social system designed to have high benefits for the community to increase access to knowledge, education, encourage creativity and innovation, and a better religious life.

Furthermore, more specifically, this study is limited to issues in the religious field as follows; 1) How is the existence of a collection of religious reading materials in the Muda Bhakti Library; 2) What are the opportunities, challenges, and obstacles in managing the Young Bhakti Library; and 3) Is there a role for the community's reading of religious readings on their religious behavior.

\section{KNOWING BHAKTI YOUNG LIBRARY}

The Young Bhakti Library is located in Ngablak Village, Srumbung District, Magelang Regency with a location at the foot of Mount Merapi, Magelang Regency.

Figure 1. Location of the Young Bhakti Library

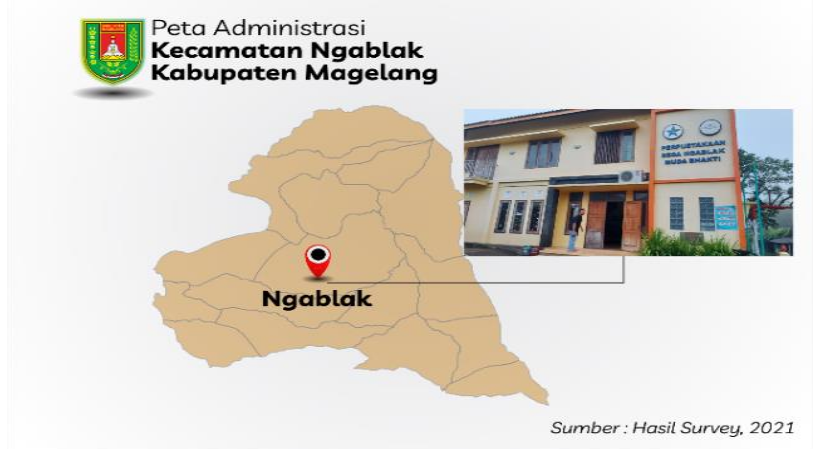

Source: Bappeda Kab. Magelang 2021

Method and Its Application to a Forest-Certification Case," Forest Policy and Economics, 2000; D W Pickton and S Wright, "What's Swot in Strategic Analysis?," Strategic Change, 1998.
The demographic portrait of Ngablak Village according to data from the Department of Community Empowerment, Village Population and Civil Registration of Central Java Province in 2020 has a total population of 2,450 people. It has a number of Family Heads (KK) as many as 782 with the distribution of each by gender as shown in the following figure.

Figure 2. Distribution of Population and Kartu Keluarga (KK) in Ngablak Srumbung Village in 2020

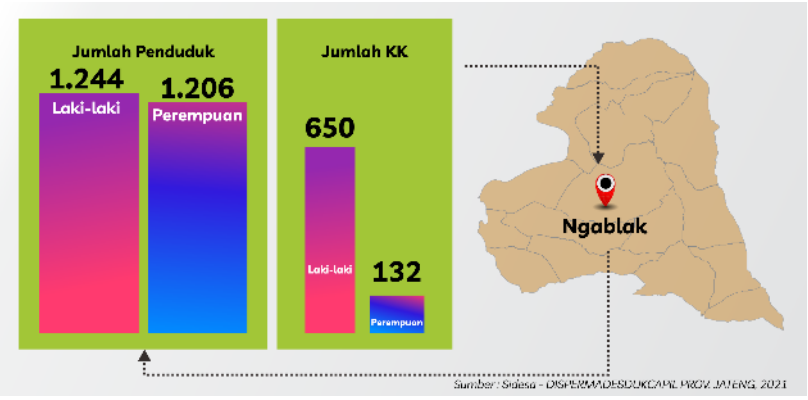

Source: Bappeda Kab. Magelang 2021

As for the description of the percentage distribution of the population, $99.2 \%$ are Muslims, while the rest are Christians and Catholics. Education is not/not yet school as much as $4.3 \%$, not yet finished elementary school as much as $2.4 \%$, elementary school graduates as much as $40.2 \%$, junior high school graduates as much as $25.2 \%$, high school graduates as much as $23.5 \%$, and the remaining $4.4 \%$ are Bachelors from D1 to S1. The distribution of the population according to religion and education in Ngablak Village is shown in the following figure.

Figure 3. Population Distribution by Religion and Education in Ngablak Srumbung Village in 2020

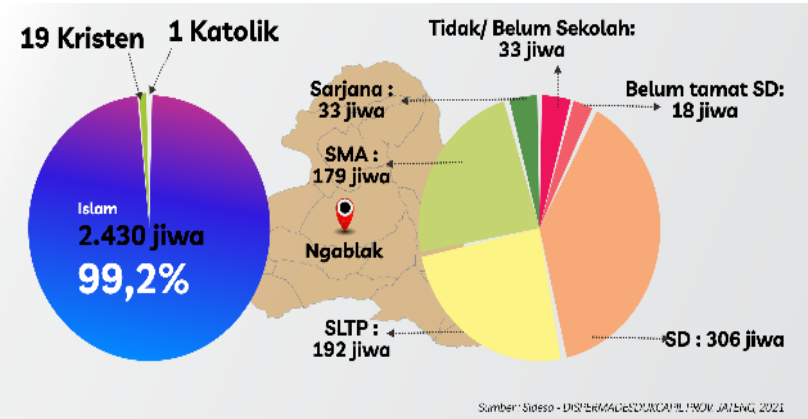

Source: Bappeda Kab. Magelang 2021 
This condition shows the population's capacity that requires literacy to increase their income, both in the context of religious life and in the field of education. The efforts made by the village by building a library are a positive and real step, although it still requires sustainable development in the implementation of its agenda and programs. The forerunner of the Young Bhakti Library was originally from Karang Taruna, which had units under it, and one of them was a village library unit. In 1985 the Karang Taruna Ngablak Village had been a role model until 1995, it was still operational. The youth organization building results from nongovernmental organizations, and the library section is active. Many children gather here because of its strategic location. The initial youth organization building was only $3 \times 6$ meters wide. In the early days, the collection was very minimal, so the collection of books and magazines of $\mathrm{Mr}$. Muhadi, the initiator of the village library, was directed to the Muda Bhakti Library; even today, Mr Muhadi's subscription magazines such as Joko Lodhang are still kept in the Muda Bhakti Library which is expected to attract readers from mature. From here, too, when students visit Kuliah Kerja Nyata $(\mathrm{KKN})$, one of the programs carried out is to prepare a proposal for the procurement of books. When Magelang Regency held a library competition, the sub-district appointed the Young Bhakti Library to represent it, so that it won first place at the district level. Then also represented at the provincial level even though he had not yet become a champion at that time ${ }^{21}$.

Since its inception, when it was still part of the Youth Organization, the public's interest was quite good. At that time, libraries with minimal collections had a strategy to organize book collections in a row to display cover pages, especially magazines and children's books. Even though the public's interest is quite good, it still has not reached the need for reading materials

${ }^{21}$ Muhadi (Subject), Interview, 16 Juni 2021 such as people who are more 'reading literate' or academics, therefore reading displays are $\mathrm{crucial}^{22}$.

\section{YOUNG BHAKTI LIBRARY COLLECTION}

The existence of this library has experienced its ups and downs. The library's location in a disaster-prone area has an impact on its physical condition, as well as on the collection of reading materials. At least twice the library was damaged, resulting in reduced or damaged reading materials. Then slowly, the library gets up, raises book donations, submits proposals, and purchases new collections.

In addition to a collection of children's books and magazines, the Muda Bhakti Library has several collections of religious books. The majority of the residents of Ngablak Village are Muslim as shown in Figure 3. It also affects a collection of religious books in Permubha, almost $100 \%$ of Islamic religious books. There are less than ten religious books classified as other religions (Christian/Catholic) resulting from a grant and have not been included in the Permubha catalog. Therefore, the discussion of religious collections in this article is limited to Islamic religious collections.

After the manual observation process on the religious collections in this library, it can then be detailed again based on the scientific classification $^{23}$. Most Islamic collections are books related to morality and Sufism, history books and biographies of figures, fiqh books, followed by other Islamic books. Moral and Sufism books are abundant and easy to find in various bookstores with relatively low prices. The collection of 2021

22 Milta E and Muhadi (Subjects), Interview ,16 Juni

${ }^{23}$ Muh Kailani Er, ed., Daftar Tajuk Subyek Islam Dan Sistem Klasifikasi Islam: Adaptasi Dan Perluasan DDC Seksi Islam (Jakarta: Puslitbang Lektur Agama Badan Litbang Agama Departemen Agama, 2003); Bisri Ruchani et al., Katalog Naskah Keagamaan Madura Volume 1 Sumenep, ed. Moch. Lukluil Maknun and Bisri Ruchani (Yogyakarta: Arti Bumi Intaran, 2017). 
biographies of figures and histories in this library results from donations whose share is directed to children's reading so that they are more familiar with history and Muslim figures. Details of Islamic classification can be seen in Figure 4.

Figure 4. Classification of Islamic Scientific Library Collection

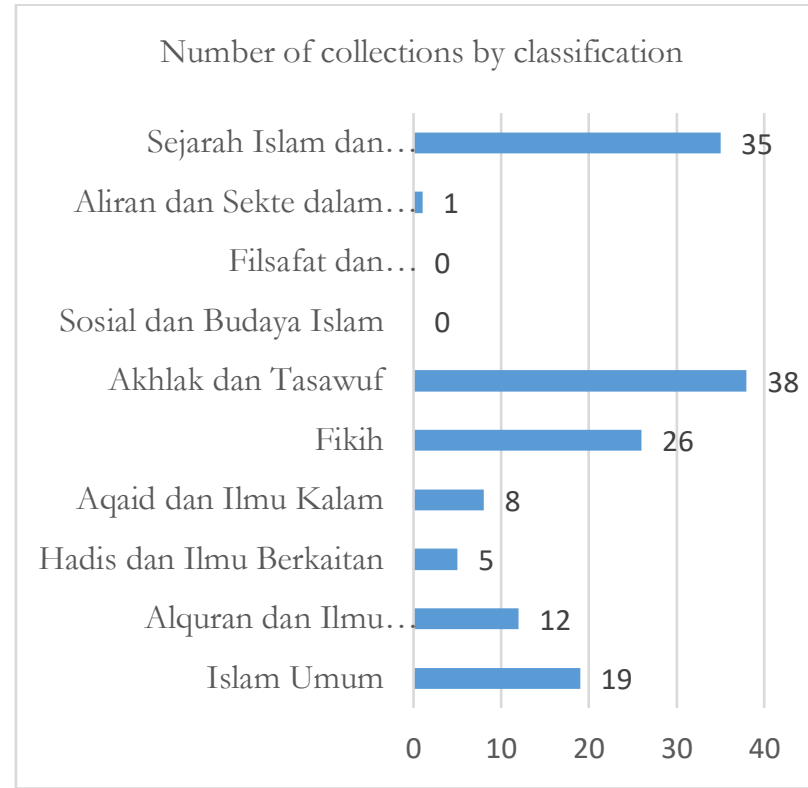

Source: Processed From Research Results June 2021

From the existing data, the number of collections of religious books in the Muda Bhakti Library is approximately 145 book titles and library visitors borrow $40 \%$ of the collection of religious books. The percentage of borrowers of religious books in the library based on the category of profession/type of work during the period 2020-2021 is shown in Figure 5.

Figure 5. Borrower of Islamic Religious Collection Books

Peminjam berdasar profesi

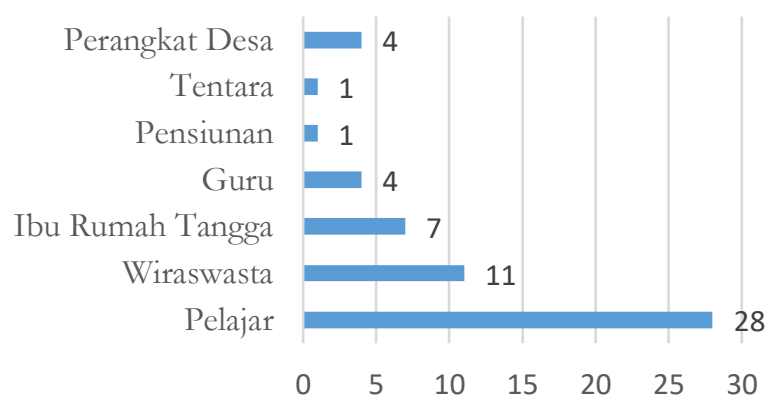

Source: Young Bhakti Library Main Book
The number of borrowers in Figure 5 is not the same as the number of visitors reading on the spot. For example, in the village, students often come in turns from nearby schools (one madrasah ibtidaiyah/MI, and two elementary schools/SD). Especially during the Covid-19 pandemic which closed offline classes, the school in collaboration with the library held classes in rotation, both online and offline by coming directly to class. Likewise, housewives who accompany their children to do schoolwork often come to the library even though they do not borrow reading books to take home. They, both students and mothers who take their children, can choose for themselves on the collection shelf and read or work on assignments at the reading table provided (picture 6) or even in the wider secondfloor hall for classes ${ }^{24}$.

Figure 6. Collection Room and Permubha Reading Table

\begin{tabular}{|l|l|}
\hline The collection room & $\begin{array}{l}\text { Discussion with the } \\
\text { initiators of Permubha }\end{array}$ \\
\hline
\end{tabular}

Source: Researcher documentation

\section{LIBRARY GOVERNANCE SWOT ANALYSIS}

Based on the guidelines for library management and aspects found by researchers in the field, either through observation or interviews with informants, the following SWOT analysis can be conveyed by Permubha.

Table 1. Strength

\begin{tabular}{ccc}
\hline No. & \multicolumn{1}{c}{ Question } & Response \\
\hline 1 & $\begin{array}{l}\text { Is there an information } \\
\text { disclosure and access policy }\end{array}$ & There is \\
\hline 2 & Is there communication in & There is \\
\hline \multicolumn{2}{c}{24} & Milta E and Siti K (Subjects), Interview, 18 Juni
\end{tabular}




\begin{tabular}{cll}
\hline \multicolumn{2}{l}{ service } & \\
\hline 3 & $\begin{array}{l}\text { Is there a circulation of library } \\
\text { facilities }\end{array}$ & There is \\
\hline 4 & $\begin{array}{l}\text { Is there a library reference } \\
\text { service }\end{array}$ & $\begin{array}{l}\text { Do not } \\
\text { know }\end{array}$ \\
\hline 5 & $\begin{array}{l}\text { Are there types of library } \\
\text { reference books? }\end{array}$ & Do not \\
& know \\
\hline 6 & $\begin{array}{l}\text { Is there a means of meeting } \\
\text { information? }\end{array}$ & Do not \\
\hline 7 & Is there a library service officer & Do not \\
& & know \\
\hline 8 & $\begin{array}{l}\text { Is there a responsibility to } \\
\text { protect privacy rights? }\end{array}$ & Do not \\
& know \\
\hline 9 & Is there a library policy & Do not \\
& & know \\
\hline 10 & Is there management sustainable & Do not \\
& administration & know \\
\hline
\end{tabular}

Table 1 shows that Permubha's strength is still found in 3 things, namely openness, communication, and circulation, which as seen in Figure 7 is at baseline 3 which indicates the maximum value. Permubha has not provided a reference book, although it is not too urgent in terms of use and need. Other things have not been sufficiently identified or still need to be developed.

Figure 7 Permubha Strength Ranking

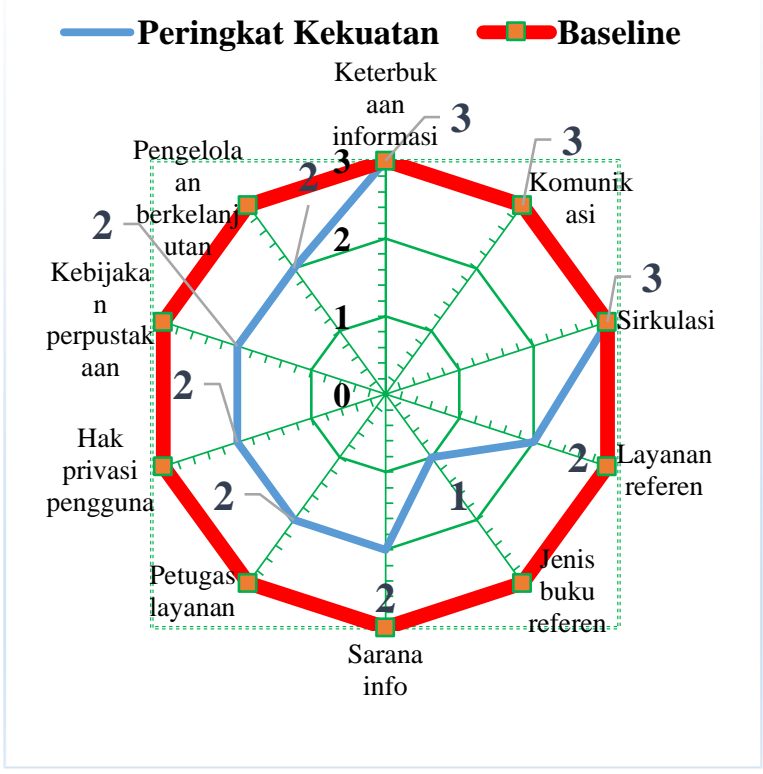

Table 2. Weaknesses

\begin{tabular}{rll}
\hline No. & \multicolumn{1}{c}{ Question } & Response \\
\hline 1 & User education activities & There is \\
\hline 2 & $\begin{array}{l}\text { Availability of Islamic } \\
\text { Religion Collection }\end{array}$ & There is \\
\hline 3 & $\begin{array}{l}\text { Availability of Collections } \\
\text { of Non-Muslim Religions }\end{array}$ & $\begin{array}{l}\text { Do not } \\
\text { know }\end{array}$ \\
\hline 4 & Source of library funds & There is \\
\hline 5 & $\begin{array}{l}\text { The existence of a } \\
\text { computerized catalog }\end{array}$ & $\begin{array}{l}\text { Do not } \\
\text { know }\end{array}$ \\
\hline 6 & $\begin{array}{l}\text { Presence of } \\
\text { advertisements/information }\end{array}$ & $\begin{array}{l}\text { Do not } \\
\text { know }\end{array}$ \\
\hline
\end{tabular}

Table 2 shows that Permubha's weaknesses are still in one main thing, namely the computerized system, especially in the catalog. It can be seen in Figure 8 which shows the computerized catalog is at the baseline 3. The next weakness is still tentative, namely the absence or insufficient collection of non-Muslim religious readings, even the collection of Islamic religious readings still needs to be improved. The source of Permubha's funds has indeed been budgeted by the village government and donations from community donations through the 'salak library' program, where each salak farmer is asked to donate 1 tree, the proceeds of which are collected to support the sustainability of the library. However, the amount of funds owned is still not maximized to run library operations, especially the procurement of books. Advertisements and information related to libraries also still need to be improved, even though during the disaster season, the library becomes the main reference for absorbing and updating information because it is used as a disaster post ${ }^{25}$.

25 Milta E and Muhadi (Subjects), Interview, 16 Juni 
Figure 8. Rating of Permubha Weaknesses

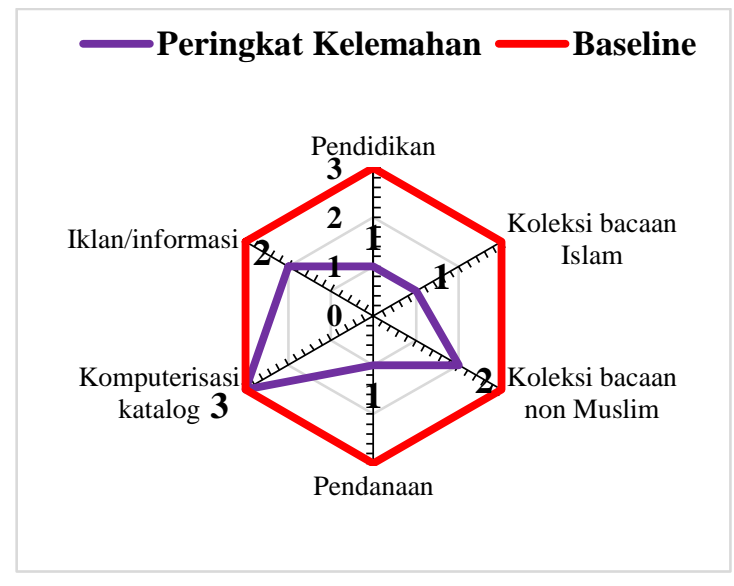

Table 3. Opportunities

\begin{tabular}{lll}
\hline No & Pertanyaan & Respon \\
\hline 1 & $\begin{array}{l}\text { There is professionalism } \\
\text { knowledge, skills, work attitude, } \\
\text { social interaction }\end{array}$ & Maybe \\
\hline 2 & $\begin{array}{l}\text { The existence of descriptive and } \\
\text { normative officer ethics }\end{array}$ & Yes \\
\hline 3 & $\begin{array}{l}\text { There is a responsibility to provide } \\
\text { request services, help search, } \\
\text { search, clarify info }\end{array}$ & Yes \\
\hline 4 & $\begin{array}{l}\text { Build out network } \\
\text { 5 }\end{array}$ & $\begin{array}{l}\text { Maximizing the role of citizen } \\
\text { donations }\end{array}$ \\
\hline 6 & $\begin{array}{l}\text { Maximizing facilities and } \\
\text { infrastructure }\end{array}$ & Yes \\
\hline
\end{tabular}

Table 3 shows several aspects of the opportunities that Permubha has and can develop such as ethics and officer responsibilities in serving users. Donations from residents that the initiators and citizen awareness have initiated need to be maintained and increased by various developments. The facilities and infrastructure in the name of the Permubha library are also quite adequate, this is because it is fully supported by the village and is based on the youth youth embryo which has been active previously ${ }^{26}$. Meeting and activity halls, collection of reading books, computers and internet networks, and strategic locations can be further developed to

${ }^{26}$ Muhadi (Subject), Interview, 16 Juni 2021 attract residents' interest from gathering to using reading materials. Furthermore, the potential to build networks to external parties still needs to be improved and is very wide open. So far they have been known by the government, educational institutions, and also the community. Permubha's potential strength map seen from several aspects is quite large as shown in Figure 9.

Figure 9. Ranking of Permubha Opportunities
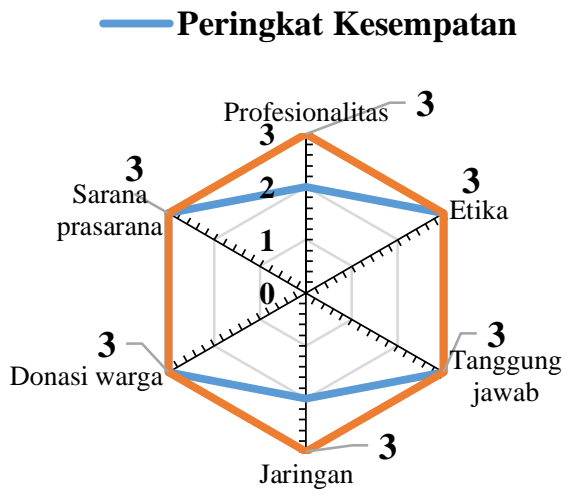

Table 4. Challenges

\begin{tabular}{lll}
\hline No & Question & $\begin{array}{l}\text { Respon } \\
\text { s }\end{array}$ \\
\hline 1 & Excellent service strategy & Maybe \\
\hline 2 & Service development & Maybe \\
\hline 3 & Service evaluation & Yes \\
\hline 4 & Librarian education & Yes \\
\hline 5 & $\begin{array}{l}\text { Improved qualifications: understanding } \\
\text { of science, technology, institutions, the } \\
\text { world of education, and so on }\end{array}$ & Yes \\
\hline 6 & $\begin{array}{l}\text { Increased responsibility for education, } \\
\text { educating staff, and participation }\end{array}$ & Yes \\
\hline
\end{tabular}

Table 4 shows that the strategy and service development is still a challenge that may need to be improved even though it is already running. Service evaluation is carried out at the end of each year, and so far it has not been maximized due to various related things, such as the condition of library staff and funding. The education of library staff, apart from self-taught learning and inter-officer learning, has also been 
invited several times to activities held by the government. Of course, there are still wide opportunities to develop it, which requires support, including the next two aspects. Permubha's challenge strength map seen from several aspects is quite large as shown in Figure 10.

Figure 10. Permubha Challenge Ranking

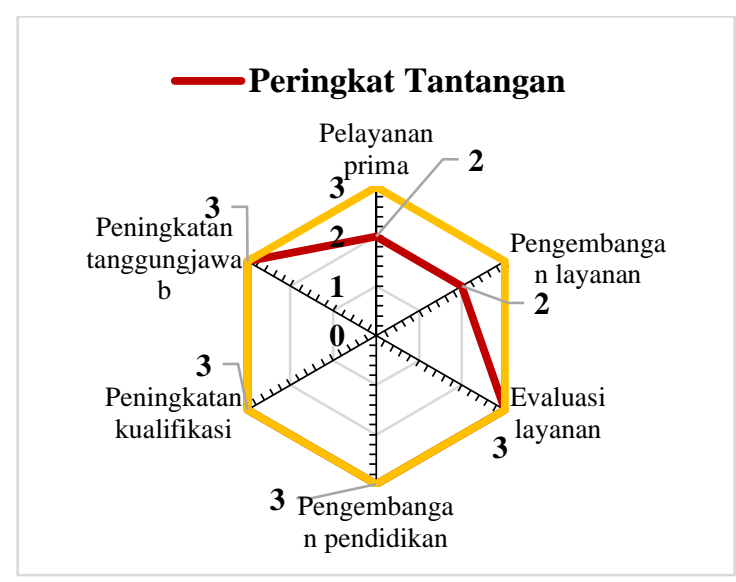

After obtaining measurements of each aspect of the Permubha SWOT, then the overall map can be measured as shown in Figure 11.

Figure 11. Overall SWOT Map of Permubha

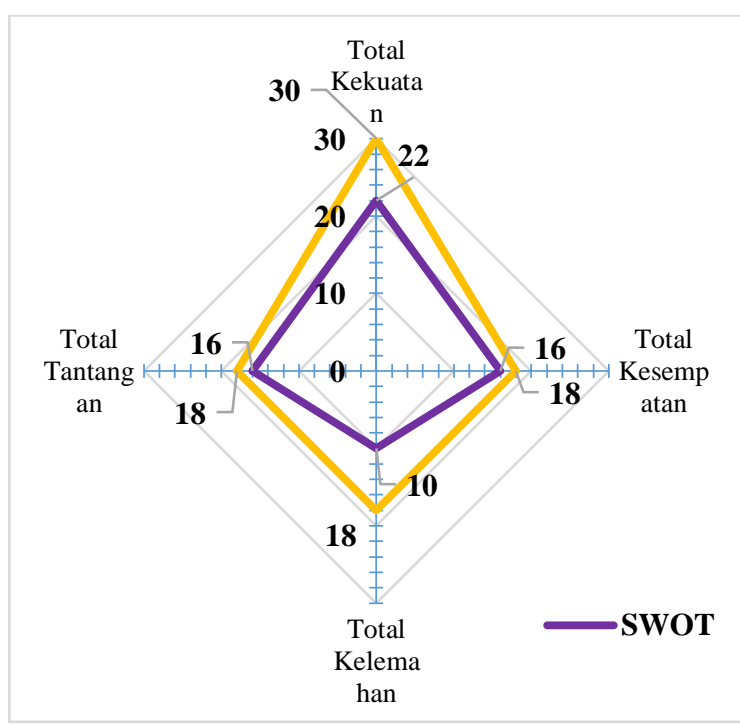

The description of Figure 10 can be clarified as follows. Permubha's total strength count is 22 from baseline $30(73 \%)$; total opportunity is worth 16 from baseline 18 (88\%); total weakness is 10 from baseline $18(55 \%)$; and a total of 16 challenges from baseline 18 (88\%).

\section{FEELING THE SOCIAL RELIGIOUS ROLE}

The Young Bhakti Library is located in the KRB 3 area (a disaster-prone area) so because of its location it has experienced several ups and downs in its development, including the Merapi eruption in 2006. The eruption of Merapi caused the library's roof to collapse in several parts and damaged most of the infrastructure. After the bookshelves were in place, deliberation decided to ask for donations of used books that were still worth reading to every citizen. After the residents' enthusiasm was high to donate books, the village government took the initiative to allocate a separate village fund for the procurement of books. In 2010 the Muda Bhakti Library ran aground again with another, larger eruption of Merapi. However, supported by the people's enthusiasm and previous experiences, in 2013 the library was able to rise again. The library, during a disaster, is a strategic location for residents to gather and seek information. When a disaster happened, the village and the library manager intended all the earliest information to be in the library. Any information related to disaster anticipation will be centered here. Therefore, on the one hand, the Merapi disaster has become a momentum to attract residents to come closer and take advantage of the ${ }^{27}$. Based on this historical narrative, Permubha has tried to take an important role in the lives of residents in terms of information, especially during disasters.

The Young Bhakti Library has several advantages and potentials, including representative buildings and facilities, the strategic location of the library in the middle of the village and close to SD and MI, and the high concern

${ }^{27}$ Muhadi (Subject), Interview, 16 Juni 2021 
and support from the Ngablak Village Government towards the Muda Bhakti Library. This can be seen from the constant budgeting of part of the village funds for the activities and welfare of librarian. The Village Government always budgets $1.85 \%$ of village funds, which nominally fluctuates around 18,000,000 per year. In addition, various routine social and religious activities are also carried out at Permubha. Among these activities were training on disaster mitigation of the Merapi eruption, training for community empowerment of salak farmers, Peringatan Hari Besar Islam (PHBI), and training as a Master of Ceremonies (MC) as well as speech training using the Javanese language. Several activities were carried out as a literacy center for students at the Madrasah Ibtidaiyah/Elementary School level and a place to shift the focus of children who are starting to be negatively affected by game addiction. Internet access makes it easy for teachers to add teaching materials for students and flexible library service opening hours make it friendly for children's activities ${ }^{28}$.

As for seeing and measuring the role of libraries, collections, and reading results on the socio-religious aspects of society, of course, more detailed measuring tools are needed. It is still a common problem in Indonesia related to low literacy, even by actors who should be very active in literacy such as teachers and students ${ }^{29}$. The organizers and initiators have not made many significant statements regarding this socioreligious role. For example, whether a library and a collection of existing religious readings make the

28 Milta Eliza dan Anggraeni (Subject), Interview, 16 Juni 2021

29 Asep Saefulloh, "Minat Baca Dan Literatur Guru Pendidikan Agama Islam (PAI) SMA Di Kota Tangerang, Banten," Journal Dialog 41, no. 1 (2018), https://doi.org/https://doi.org/10.47655/dialog.v41i1.283; Muslimin, "Penumbuhan Budaya Literasi Melalui Peningkatan Minat Baca Masyarakat Desa," Cakrawala Pendidikan 37, no. 1 (2018): 107-18; M. Ihsan, "Upaya Penguatan Pendidikan Agama Islam Berbasis Literasi Pesantren," LIBRARIA: Jurnal Perpustakaan 6, no. 1 (2018): 175, https://doi.org/10.21043/libraria.v6i1.3832. community more religious and knowledgeable. Nevertheless, Permubha's targets and efforts are no less important, namely introducing, functioning, and attracting residents to be close to the library. "We will be very happy if people come, take advantage of the reading collection, and make the library a comfortable gathering place" ${ }^{30}$. Thus, the new librarian can see/measure the interest of the residents to come, choose which books to read, and borrow books about religion.

In addition to the advantages and potential, there are several shortcomings and challenges that Permubha has as stated by officers and visitors. Among the shortcomings and challenges are the low enthusiasm and concern of the younger generation in every library activity agenda/program, the lack of budget funds for the procurement of new library collection books, the low quality of the human resources of librarian so that the arrangement of book collections is still not regular, the lack of officers in the library who supervise children's visitors when carrying out activities in the library, and the lack of interesting religious readings for children of basic education age $^{31}$.

One of the interesting things that can be used as an example is Mrs. Anggraeni's statement regarding the correlation between reading interest and religious behavior, which happened to one of her student's parents named Muhammad al Fatih. Where the reason behind giving his name is because his mother who is a housewife often visits the library and reads the story of the Islamic hero who conquered Constantinople, Sultan Muhammad al Fatih.

If we look closely, the number of religious book titles borrowed by visitors reaches $40 \%$, indicating that there is an opportunity for the

${ }^{30}$ Muhadi (Subject), Interview, 16 Juni 2021

31 Milta Eliza dan Anggraeni (Subjects), Interview, 16 Juni 2021 
Muda Bhakti Library to increase its role in the socio-economic realm and the religious realm. Therefore, the library's organizers should be able to capture the dynamics of the interest and diversity of the surrounding community to increase the collection of religious books that are of interest to the community. In addition, the implementation of PHBI activities carried out in the library is also expected to provide a positive role for the religious life of the Ngablak Village community.

\section{CONCLUSION}

The Muda Bhakti Library as a social inclusion-based library has given a positive role to the socio-economic and religious life of the Ngablak Village community. The role of inclusion in the Permubha case emphasizes its position as a bridge of knowledge and information for people in rural areas, areas far from the city center, even in areas prone to natural disasters (Mount Merapi). An inclusive role by eliminating discrimination is carried out by implementing community programs that all citizens can follow to increase economic resilience, social interaction, and the religious life of the local community. Information disclosure and access policies, communication in services, and circulation of library facilities are Permubha's strengths that deserve to be maintained and continuously improved. However, implementing an inclusionbased library in Permubha cannot be separated from its weaknesses, including the catalog service, which is still manual and not computer-based. It is certainly a significant obstacle in providing information on the availability of library collections quickly for the community. The solution to the existing weaknesses can be done by taking advantage of the opportunities that Permubha has, namely the use of donations from residents for the procurement of computers to realize catalog computerization. It is also a challenge for Permubha to improve the competence of Permubha officers so that they can provide computer-based services.

By using a SWOT analysis by measuring on a scale of 1-3, a map/potential of each strength, weakness, obstacle, and challenge of Permubha management has been obtained with more certainty. As for measuring the role of the existence of a library on the socio-religious behavior of residents, the results have not been obtained by using a SWOT analysis. Excavation and data analysis by maximizing observations and interviews deserves to be tested further in the next study.

\section{REFERENCES}

Adhi, H S. "Peran Pustakawan Dalam Mewujudkan Layanan Perpustakaan Berbasis Inklusi Sosial Melalui Program Proliterasiku." Jurnal IPI (Ikatan Pustakawan Indonesia). ipi.web.id, 2018.

Antoro, Billy. Gerakan Literasi Sekolah: Dari Pucuk Hingga Akar. 1st ed. Jakarta: Direktorat Jenderal Pendidikan Dasar dan Menengah Kementerian Pendidikan dan Kebudayaan, 2017.

https://doi.org/10.1017/S003329170003660 6.

Darmayanti, R. "Membangun Budaya Literasi Informasi Bagi Masyarakat Kampus." IQRA: Jurnal Ilmu Perpustakaan Dan Informasi (e .... jurnal.uinsu.ac.id, 2016.

Eliza, Milta. "Pofil Perpustakaan Muda Bhakti Desa Ngablak, Kec. Srumbung, Kab. Magelang." Kabupaten Magelang: Perpustakaan Muda Bhakti, 2019.

Haryanto, Feri Dwi. "Strategi Pengembangan Minat Baca Di Perpustakaan Muda Bhakti." E-Jurnal Skripsi Program Studi Teknologi Pendidikan 8, no. 5 (2019).

Hill, T, and R Westbrook. "SWOT Analysis: It's Time for a Product Recall." Long Range Planning, 1997.

Houben, G, K Lenie, and $\mathrm{K}$ Vanhoof. "A 
Knowledge-Based SWOT-Analysis System as an Instrument for Strategic Planning in Small and Medium Sized Enterprises." Decision Support Systems, 1999.

Ihsan, M. "Upaya Penguatan Pendidikan Agama Islam Berbasis Literasi Pesantren." LIBRARLA: Jurnal Perpustakaan 6, no. 1 (2018):

175.

https://doi.org/10.21043/libraria.v6i1.3832.

Iswanto, Agus, Moch. Lukluil Maknun, Mustolehudin, Umi Masfiah, Subkhan Ridlo, and Roch. Aris Hidayat. "Praktik Literasi Mahasiswa Universitas Islam Negeri Di Yogyakarta, Jawa Tengah, Jawa Timur, Nusa Tenggara Barat, Dan Kalimantan Selatan.” Semarang, 2018.

Jackson, S E, A Joshi, and N L Erhardt. "Recent Research on Team and Organizational Diversity: SWOT Analysis and Implications." Journal of Management, 2003.

Jananto, A. Pandangan Sekolah Terbadap Penyelenggaraan Pendidikan Inklusif $D i$ Kabupaten Bangka Barat. repository.upi.edu, 2016.

Kailani Er, Muh, ed. Daftar Tajuk Subyek Islam Dan Sistem Klasifikasi Islam: Adaptasi Dan Perluasan DDC Seksi Islam. Jakarta: Puslitbang Lektur Agama Badan Litbang Agama Departemen Agama, 2003.

Khairunisa, K, and W Dastina. "Strategi Dinas Perpustakaan Dan Arsip Daerah (DPAD) Provinsi Jambi Dalam Mengembangkan Perpustakaan Berbasis Inklusi Sosial Untuk Mewujudkan Masyarakat ..." ... Ilmu Perpustakaan ..., 2020.

Kimiaissa'adah, N. Implementasi Gerakan Literasi Membaca Dalam Menumbubkembangkan Minat Baca Anak Usia Dini Di TK IT Mutiara Hati Semarang. lib.unnes.ac.id, 2019.

Kurttila, M, M Pesonen, J Kangas, and M Kajanus. "Utilizing the Analytic Hierarchy Process (AHP) in SWOT Analysis-a Hybrid Method and Its Application to a
Forest-Certification Case." Forest Policy and Economics, 2000.

Meinita, Hanna. "Rayakan Hari Jadi Ke-41 Tahun, Perpusnas Punya 10 Modal Wujudkan SDM Unggul." https://www.perpusnas.go.id/, 2021.

Muslimin. "Penumbuhan Budaya Literasi Melalui Peningkatan Minat Baca Masyarakat Desa." Cakrawala Pendidikan 37, no. 1 (2018): 10718.

Noor, M U. “Aplikasi Layanan Informasi Berbasis Internet Untuk Menumbuhkan Inklusi Sosial Di Perpustakaan Daerah." JIPI (Jurnal Ilmu Perpustakaan Dan Informasi), 2019.

NS, Sutarno. Manajemen Perpustakaan: Suatu Pendekatan Praktik. Jakarta: CV. Sagung Seto, 2006.

- Tanggung Jawab Perpustakaan Dalam Mengembangkan Masyarakat Informasi. Jakarta: Panta Rei, 2005.

Pickton, D W, and S Wright. "What's Swot in Strategic Analysis?” Strategic Change, 1998.

Prasetyo, W D, and D Utami. "Penguatan Perpustakaan Untuk Pembangunan: Sebuah Konsep Transformasi Berbasis Inklusi Sosial." Jurnal IPI (Ikatan Pustakawan Indonesia). ipi.web.id, 2020.

Rachman, R A, and D Sugiana. "Strategi Sukses Transformasi Perpustakaan Desa Berbasis Inklusi Sosial Untuk Masyarakat Sejahtera (Studi Pada Perpustakaan Desa Gampingan Gemar ...." Seminar Nasional MACOM .... researchgate.net, 2019.

Rahmah, Elva. Akses Dan Layanan Perpustakaan: Teori Dan Aplikasi. Jakarta: Prenadamedia Group, 2018.

Rohman, A S, and S Sukaesih. Transformasi Perpustakaan Desa Untuk Pemberdayaan Masyarakat: Studi Kasus Di Desa MargamuktiPangalengan Bandung. repository.pertanian.go.id, 2018.

Ruchani, Bisri, Subkhan Ridlo, Roch. Aris Hidayat, Umi Masfiah, and Moch. Lukluil 
Maknun. Katalog Naskah Keagamaan Madura Volume 1 Sumenep. Edited by Moch. Lukluil Maknun and Bisri Ruchani. Yogyakarta: Arti Bumi Intaran, 2017.

Saefulloh, Asep. "Minat Baca Dan Literatur Guru Pendidikan Agama Islam (PAI) SMA Di Kota Tangerang, Banten.” Journal Dialog 41, no. 1 (2018). https://doi.org/https://doi.org/10.47655/d ialog.v41i1.283.

Sembiring, G B B. “Taman Baca Pustaka Sebagai Perluasan Layanan Perpustakaan Khusus Berbasis Inklusi Sosial." ... Jaringan Informasi Antar Perpustakaan, 2020.

Sumardji, P. Mengelola Perpustakaan. 17th ed. Yogyakarta: Penerbit Kanisius, 2013.

Surachman, A. "Undang-Undang Nomor 43 Tahun 2007: Peluang Dan Tantangan Bagi Pustakawan." repository.ugm.ac.id, 2009.

Utami, D, and W D Prasetyo. "Perpustakaan Berbasis Inklusi Sosial Untuk Pembangunan Sosial-Ekonomi Masyarakat.” ... Informasi Antar Perpustakaan, 2019.

Widyanto, R. Arri, Fadilah Hasti Cahyaningtyas, Frida Wiryani, Balgis Riski Ramadhani, Dwi Ochtaviani, and Arina Amalia. "Pengelolaan Perpusdes Dengan Ingkubasi Wirausaha Di Perpustakaan Muda Bhakti Desa Ngablak Srumbung: Laporan Akhir Pengabdian Masyarakat Terpadu (PPMT) Universitas Muhammadiyah Magelang." Universitas Mubammadiyah Magelang, 2020. 